\title{
Gender and Education
}

\section{The intra-active production of normativity and difference}

\author{
Elisabeth De Schauwer, Inge Van de Putte, Inge G.E. Blockmans \& Bronwyn \\ Davies
}

To cite this article: Elisabeth De Schauwer, Inge Van de Putte, Inge G.E. Blockmans \& Bronwyn Davies (2018) The intra-active production of normativity and difference, Gender and Education, 30:5, 607-622, DOI: 10.1080/09540253.2016.1259463

To link to this article: https://doi.org/10.1080/09540253.2016.1259463

\section{Published online: 28 Nov 2016.}

Submit your article to this journal

Џll Article views: 337

View Crossmark data ¿

4

Citing articles: 5 View citing articles $\square$ 


\title{
The intra-active production of normativity and difference
}

\author{
Elisabeth De Schauwer ${ }^{a}$, Inge Van de Putte ${ }^{a}$, Inge G.E. Blockmans ${ }^{a, b}$ and \\ Bronwyn Davies ${ }^{c}$
}

${ }^{a}$ Special Needs Education, Ghent University, Ghent, Belgium; ${ }^{b}$ Interfaculty Institute of Family and Sexuality Studies, KU Leuven, Belgium; ${ }^{C}$ Youth Research Centre, University of Melbourne, Australia

\begin{abstract}
Drawing on memory stories told in a collective biography workshop about children's encounters with schooling, this paper experiments with re-imagining the child-student-subject as an 'emergent intracorporeal multiplicity' [Fritsch, K. 2015. "Desiring Disability Differently: Neoliberalism, Heterotopic Imagination and IntraCorporeal Configurations." Foucault Studies 19: 43-66, 51]. From the feminist new materialist perspective that the authors work with, the child is configured not as an entity prior to, or separate from, encounters with education systems, but emergent with-in them. This paper focuses on difference in human relations, and in particular on the intersections of disability and gender. It does so not in terms of essential characteristics of individuals, but as emergent, in-the-moment, with others. In focussing on the detail of lives-in-their-making, the authors ask, with Barad [2007. Meeting the Universe Halfway: Quantum Physics and the Entanglement of Matter and Meaning. Durham: Duke University Press], if we are interested in justice, how we are to 'understand our role in helping constitute who and what come to matter?'
\end{abstract}

\section{ARTICLE HISTORY}

Received 5 October 2015

Revised 1 April 2016

Accepted 28 April 2016

\section{KEYWORDS}

Disability; gender; difference; justice; normativity; responsibility

[Justice entails] the ongoing practice of being open and alive to each meeting, each intraaction, so that we might use our ability to respond, our responsibility, to help awaken, to breathe life into ever new possibilities for living justly. The world and its possibilities for becoming are remade in each meeting. How then shall we understand our role in helping constitute who and what come to matter? (Barad 2007, x, our emphasis)

Categorisation is standard practice for managing and governing populations - of making them governable - through making the existing forms of knowledge, or rationality, seem both reasonable and inevitable (Davies et al. 2006a). We take up the categories we have been assigned to in the process that Foucault (1997) calls governmentality - the taking up of the mentality that will make us more governable. Those categories tend to be binary categories, with one in the ascendant and one subordinated, as feminist research on gender has shown (Baker and Davies 1989). Barad (2007) invites us to extend our thinking by attending to ethics, and to the ontology and epistemology of social life. She invites us to ask of each encounter, what is being made to matter. In this spirit we turn our attention here to the practice of positioning non-normative children in terms of their subordinate

CONTACT Elisabeth De Schauwer elisabeth.deschauwer@ugent.be

This article was originally published with error. This version has been corrected. Please see Corrigendum (http://dx.doi.org/ 10.1080/09540253.2016.1274856)

(C) 2016 Informa UK Limited, trading as Taylor \& Francis Group 
category membership such that they are seen as less educable, and even as less worthy of education (Davies and Harré 1990; Davies 2008).

Positioning individuals through their subordinate category membership can be understood as a mode of linguistic marking, where the unmarked category is taken to be normal, and to be what anyone could or should be, while the marked category is that which is other to normal. Whereas boys and men may have belonged to an unmarked category, regarding themselves as simply human, or normal, girls and women have been more likely to be marked by their gender and seen as other to normative masculinity (Kimmel 1990; Davies 1993). ${ }^{1}$ Marking also takes place within these categories where hegemonic masculinity, for example, may be unmarked in relation to the category of queer, or nerd, or sook. The capability/disability binary works in the same way, where those who do not have disabilities read themselves as simply human in the way anyone can and should be. One's hegemonic or ascendant positioning is read as natural and not in need of conscious attention - it can be taken for granted. A subordinate category, such as disabled, is marked and in need of remediation in order to become like those who are deemed to be capable.

While subordinate binary categories might be used effectively for political, medical, or economic purposes, in educational contexts, we suggest, marking children in terms of their subordinate category, where that then justifies their exclusion from education on that basis, is ethically irresponsible and unjust. In this paper we experiment with new materialist concepts in order to explore the intra-active processes through which positioning in terms of subordinate categories is made to matter.

Currently in Flanders children may be excluded from regular school if they are categorised as disabled (Hall 2013). ${ }^{2}$ Such category-based decision-making, which places regular schooling outside the reach of so many, is generally accompanied by a neoliberal mode of governmentality in which responsibility is made a matter for the individual: "People are responsible for the "production" of their own well-being and selfactualisation', and to be a member of the regular education system 'a specific kind of self-knowledge and self-mastery is required' (Davies 2009, Masschelein and Simons 2005, 125; Bird Claiborne et al. 2009). Children who are judged sufficiently normal to be allowed entry into regular school are generally deemed to be so to the extent that they can become 'entrepreneurs of themselves, shaping their own lives through the choices they make' (Rose 1989, 230). Each must be capable of governing him or herself to become the ideal neoliberal subject, one who is primarily a productive economic subject and capable of transforming him or herself according to the needs of the economy (Davies et al. 2006b; Martin 1997).

That responsibilised and responsive neoliberal subject is nevertheless still individualised and understood in liberal humanist terms as an entity; that is, as someone who exists independent of their context and who, by an act of will, can nevertheless become whatever it is deemed appropriate s/he should be. In order to address Barad's question in this context, we focus not on that will-driven entity, but on the 'emergent intracorporeal multiplicities of life' (Fritsch 2015, 51). In line with the new materialist perspective we are interested in the moment-by-moment production of possibilities among all those involved - not just humans but also discourses, values, and the spatialmaterial elements of schools. As Barad $(2007,396)$ concludes in Meeting the Universe Halfway: 
The world and its possibilities for becoming are remade with each moment. If we hold on to the belief that the world is made of individual entities, it is hard to see how even our best, most well-intentioned calculations for right action can avoid tearing holes in the delicate tissue structure of entanglements that the lifeblood of the world runs through. Intra-acting responsibly as part of the world means taking account of the entangled phenomena that are intrinsic to the world's vitality and being responsive to the possibilities that might help us and it flourish.

It is those entangled phenomena, that the 'lifeblood of the world runs through', that we set out to explore in this paper, with the hope, on the one hand, of enabling a flourishing of lives that are currently categorised and abjected as non-normative, and on the other, of opening up a feminist new materialist perspective in the sphere of education more broadly.

In order to engage in this exploration of thinking differently, in our pursuit of Barad's question, how 'shall we understand our role in helping constitute who and what come to matter?' (Barad 2007, x), we have, together, engaged in a collective biography workshop, where we have told our own stories of being school children, and of working with school children categorised as disabled. ${ }^{3}$ We will draw on three of those memory stories to explore the processes of normalisation and of ab-normalisation at work in children's lives.

In challenging the categorising-as-usual through which children are excluded in current education systems, we are interested in the way that the production of some children as normative subjects is, in being unmarked, naturalised, as if it were the spontaneous expression of their intrinsic normality, an intrinsic normality that anyone could, and should, accomplish. Through our memory stories, and the concepts we put to work in relation to them, we explore the production of the imagined normative subject of neoliberalism and the emergent intracorporeal entanglements through which each of us is made, and goes on being made, in the ongoing processes of intra-active becoming (cf. Davies et al. 2001). We use Barad's (2007) term intra-active here, in contrast to interaction, to signal the conceptual movement away from separate entities engaging with each other (interaction), toward the unfolding process of becoming in relation to others, where each one is capable of affecting and being affected by the other (intra-action).

\section{Rethinking disability as multiplicity}

Despite the conceptual, practical and policy work that has been done in disability studies, the 'problem of disability', has been naturalised and simplified in the social/political imagination such that it has become an individualised 'monolithic fact of the body' (Kafer 2013, 4). A body defined as in itself disabled can be read as incomplete, lacking, or less than human, and thus as not entitled to belong in regular schools. This has some similarities to the way the female body was defined as the problem in early movements for gender inclusion. Girls could not be included, for example, because there were no female toilets, or because intellectual activity would rob girls of their reproductive powers, or girls and women were not actually human. Categorisation can mark the nonnormative as being other to those who can be recognised as naturally belonging.

That naturalised belonging, Fritsch points out, is, from the point of view of those categorised as disabled, a masquerade performed by 'the autonomous, rational subject that can smoothly move his body in accordance with what is considered acceptable and 
appropriate within the social sphere' (Fritsch 2015, 48). From such an unmarked, autonomous position, it is easy enough to see one's own being as normal and natural, and as being the way it should be. Normativity is thus produced as a morally ascendant and natural state of being, without normative subjects ever needing to pay attention to the way ableism, sexism, racism, and homophobia are being produced through those same processes (Hehir 2005).

Becoming an unmarked subject, however, as Davies et al. (2001) demonstrated, is never finally accomplished by anyone. It is always an emergent work in progress. Yet those who do not or cannot accomplish themselves as the unmarked subject, may be read as a threat to the normative order itself insofar as they are read as unwilling to do that work that everyone must do (Shildrick 2002). From that normative position it seems obvious that those who are different must, or at least should, want to minimise the evidence of their difference through medical and prosthetic rehabilitation, or through pedagogical interventions in special schools that enable them to become appropriate 'entrepreneurs of themselves, shaping their own lives through the choices they make' (Rose 1989, 230; Laws and Davies 2000).

Drawing on the memory stories, told in a collective biography workshop, about variously abled children's encounters with early schooling, we explore how a feminist new materialist approach can open up a new conceptual space in thinking about education and difference. In what follows, we develop a diffractive analysis of the entangled relations between ability, gender and the social imagination. We consider Fritsch's challenge that what we need is to reconfigure 'how disability emerges, with whom it emerges, and where' (Fritsch 2015, 45), opening up the space of imagination to reading our encounters as 'an intra-corporeal, non-anthropocentric multiplicity that exceeds the individualized human body inscribed by neoliberal capitalism' (Fritsch 2015, 45).

\section{Collective biography as a diffractive methodology}

Collective biography is, in Barad's (2007) sense, a diffractive methodology, conceptually and in practice. Reflection and reflexivity have become taken-for-granted metaphors for conceptualising what we do in qualitative research, so diffraction as metaphor and practice makes for an interesting shift in thinking-as-usual. ${ }^{4}$ Whereas reflection and reflexivity might document categories of difference into which we can each be sorted, diffraction is itself implicated in the process whereby a difference is made. What a diffractive methodology sets out to do is to track the interference patterns, and discover from them the ongoing processes through which the world creates, and goes on creating itself. A diffractive approach opens up within the research an onto-epistemological space of encounter.

The concept of encounter in turn focuses attention on the entangled intra-active processes through which subjects, singly and collectively, come into being (Davies 2014). The diffractive researcher's task is not to tell of something or someone that exists independent of, or prior to, the research encounter, but to access that which is becoming true, ontologically and epistemologically, in the moment of encounter. In telling, writing, reading, listening to and re-writing our memory stories, we are not accessing what was once true, but opening up a space in which the new can emerge. A research encounter is in this sense experimental - researchers working diffractively do not know in advance what onto-epistemological knowledge will emerge from it and how that knowledge will matter. 
Before any collective biography workshop the participants select materials to read that will help open up the space of conceptualising the problem they are planning to focus on. For the workshop that we draw on in this paper, we read in particular Davies' (2014) Listening to children: Being and Becoming, focussing on her analysis of the concepts of difference and differenciation. Three of us had already written papers together, where we drew on work by Shildrick, Butler and Deleuze. In this workshop our plan was to focus on the importance of intra-active encounters with difference, where each one of us affects, and is affected by, others.

Our methodology of collective biography has emerged over the last two decades as an intra-active and emergent set of concepts and practices that de-individualise those doing the research, re-constituting them in and as an entangled emergent multiplicity. It de-individualises those subjects who emerge in the memory stories themselves (Davies and Gannon 2006, 2009, 2013), not positioning them as entities who pre-exist the research but as beings 'mutually implicated' in their 'differential becoming' (Barad 2008, 147). It enables us to explore the entangled phenomena of those beings who emerge in our memories with their 'differential becomings', their particular 'material (re)configurings of the world' and with their 'shifting boundaries and properties that stabilize and destabilize' (Barad 2008, 136).

Our mode of working was compatible with the conceptual analytic work we wanted to do in becoming aware of how subordinate categories are made to matter, and of how they might be made to matter differently.

In choosing a collective biography topic, and in the generation of memory stories, we seek not the individualised memory, whose function is to reveal who the teller or the told is as an individual, but the emergent, multiple, yet molecular and very specific memory the memory that takes us close to the surfaces of what it is to be emergent in all the entanglements of the particular moments that come to the surface of our collective storying. By attending to those emergent entanglements we sought to move beyond epistemological individualism and also to some extent beyond categorisation.

Collective biography takes as its beginning point an understanding of being as always open, in motion, and continuous, a becoming with the being of others, and with other elements of the material world. The practices of collective biography work with the specificity of the onto-epistemological being of each subject/researcher while at the same time seeing the lines of force at play, through which being is made possible.

The emergent listening that Davies (2014; forthcoming) writes about, as integral to working with children, is also integral to the intra-actions within the processes of collective biography itself. Such listening takes us beyond moralistic judgments that trap us inside endless repetitions, and toward an ethical recognition of the other and an affective openness to emergent entangled differences. That openness to encounters with the other is not just to encounters with other humans, but also to the material world in all its manifestations - a material and social world that one is emergent with. This is a research that does not already know what is right and proper, but is experimental, courageous, open and evolving, and always mindful of the being of others, both human and non-human. That, at least, was our ambition.

For this collective biography workshop, the four authors worked together for three days in an apartment that created its own set of unexpected and sometimes hilarious challenges. We were in Chicago, in May 2015, on our way to the ICQI ${ }^{5}$ conference, three of 
us from Belgium and one from Australia, in a down-at-heels Chicago neighbourhood, in a house that could only be described as weird, which one of us had found on Airbnb. To our collective amazement we found it was decorated with skeletons, crucifixes, screaming faces, large crowned bunnies, and lewd little pink plastic men, with the word thug written in neon lights in large letters across the living room wall.

At the beginning we sat, rather uncomfortably, around a foldable table that was covered in a white sheet, and began the work of telling and listening to each other's memories. We escaped out into Chicago parkland whenever the weather permitted, or into nearby coffee shops, hyper-aware of how the space we had inadvertently found ourselves in made us uncomfortable. The task we had set ourselves for the three days of the workshop was to work with memories of how differences get made, are made to matter. Perhaps fortuitously, and without planning that it be so, we had found ourselves in a space that screamed at us that we did not belong there.

We had agreed to work with memories that were linked to both lines of ascent and descent (Bergson 1998), to encounters with differences, to longing to belong, and to not belonging. The stories we told were not stories we planned to tell in some orderly method of 'data collection' (Lather and St. Pierre 2013). Rather they emerged in a diffractive encounter with each other's memories, with each other's embodied presence as we told and wrote and read out loud our stories, and listened to and questioned each other's stories until we could imagine being there, with-in them. The stories in turn were entangled with the place we were in, with the material we had read, the concepts we were working with, and with the other people involved in our stories. We were specifically not telling of something in language that existed somewhere/sometime else, but engaged in ontoepistemological encounters in which we were re-configuring our knowledge of difference.

After we had thus worked our way into our own and each other's stories, we each wrote our after-thoughts in relation to our own stories, exploring the links between each particular memory, the concepts, and our collective unfolding discussions in response to all of the memories. At the end of our workshop we discussed what we had come to understand through our storytelling/listening/writing/reading together, and which stories we might use to develop that understanding in the writing of this paper. We chose to include the first story, even though it is not 'about disability' because it enabled us to focus on the complex processes of normalisation at work on and through all of us. This memory reveals the work the girl had to do to find that normalised ground even while being indirectly abjected by the boys. The second story focuses on disability and masculinity and the third on disability and femininity.

Following the workshop, and drawing on both the written memories and the afterthoughts, the four of us took it in turns over a period of six months to draft and re-draft this exploration of how subordinate categories are made to matter, and how they might be made to matter differently.

\section{De- and re-territorialisation or lines of ascent and descent}

Having defined life as diffractive movement, it is also necessary, before we bring you our memory stories, and their analysis, to make sense of the remarkable capacity of the social order to stay the same. The autonomous and reasonable subject as a benchmark for what it means to be human, for example, has a marvellous capacity to re-assert itself in any work 
attempting to deconstruct it. To make sense of the way in which social change can be continually folded back into the existing social order, Bergson (1998) gave us the concepts of lines of force and in particular, lines of descent and ascent. Lines of descent he defined as made up out of citational chains that reiterate the already-known. These are more or less automatic, instantaneous repetitions. Lines of ascent, in contrast, take off into the not-yetknown. Bergson emphasises, on the one hand, the necessary interdependence of these two lines of force. On the other, he argues that the creative evolution of life emerges not from docile conformity to pre-conceived norms, the line of descent, but from the surprising and new, the line of ascent. Regularity and repetition, the line of descent, create the familiar live-able world by holding things the same, making them secure and predictable. Creative lines of ascent that open up new modes of thought and ways of being, give life its energy, its creative life-force. The lines of ascent are, at one and the same time, necessary for life, sometimes dangerous, and always subject to being re-territorialised, and thus re-incorporated back into lines of descent through habitual repetitions. It is a constant movement.

Schools and preschools become manageable through the lines of descent, through habituated, orderly repetition. The school can be described in terms of these lines of descent, as 'an organization that positions and classifies people spatially in view of controlling their behaviour and purposefully organizing individual development' (Simons and Masschelein 2008 , 689), or as Foucault would have called it, governmentality. But children come to know 'who they are', not only through these orderly repetitions or lines of descent, habituated repetitions through which they are sorted into various categories, but also, as Bird Claiborne et al. (2009) demonstrate, through ongoing, experimental lines of ascent.

Deleuze and Guattari (2004) extend Bergson's thinking about lines of ascent and descent with their concepts of de- and re-territorialisation. Listening to children at play and at work, we can see the endless repetitions through which they become skilled at taking up their allocated positions within the social order. Those repetitive practices shape the normative, normalised, embodied subjects anticipated by, and required within, the social orders of (pre)schools (Davies 2014). Normative, binary modes of speech and thought work to 'make sense' of what will count as normal and acceptable, and they work to generate and maintain what binaries are set up within that normalised order. Normal-abnormal. Male-female. Capable-disabled.

The territorialising lines of force through which those binaries are established and maintained are not only, or not even primarily experienced as oppressive. We depend on them; and the lines of ascent also depend on them. They

are comforting: they enable the chaos of the world to be reduced to discrete categories of meaning and structure. They are also necessary, for they enable us to interact with the social world, to form relations with others and to have a political 'voice'. (Malins 2007, 153)

At the same time they 'reduce the range of connections a body can make with the world around it; diminishing its potential for difference and becoming-other' (Malins 2007, 153).

Finding how to think outside territorialising lines of descent is vital work to be undertaken at this interface of inclusion and exclusion, if those who find themselves outside the meanings and structures that give comfort, and viability, are to gain access to education.

In defining difference in terms of intra-active, diffractive movements, rather than categories, we adopt the Deleuzian term differenciation here to signal the conceptual shift 
from discrete difference (dividing people as distinct entities into already-known categories), toward the continuously shifting intensities of emergent, multiple, entangled encounters (Deleuze 1994; Davies 2009). Categorisation divides human subjects into pre-conceived binary categories, with the ascendant category being read as normal and the subordinated category as other-to-normal. In contrast differenciation evokes a process we are all always engaged in, in the intensities of our emergent, mutually entangled becoming.

And now to the stories themselves.

\section{Memory stories of encounters with gender and disability}

\section{First day in preschool}

Our first remembered moment of being takes us to the first day of preschool when the lines of descent, or habitual repetitions that would make up preschool life, were not yet clear to the girl, who stands on the preschool veranda wondering what she should do. This story probes the normalisation process; as the girl stands still on the veranda she observes the boys who have collectively assembled themselves as boys-playingtogether-as-boys, and she knows herself as other to them, though she does not yet know how to differenciate her emergent, multiple self-as-schoolgirl:

The decision has been taken. She will be allowed to go to the preschool one year early. She feels excited. There will be children to play with, and a doll's house.

When she arrives at the preschool someone shows her where she must hang her school bag with her peanut butter sandwich wrapped in greaseproof paper.

She stands on the veranda watching the other children. The doll's house is on the veranda and the boys are throwing handfuls of gravel at it, seeing whose aim is the best. The gravel lands on the doll's house and on the wood of the veranda with a sharp ricocheting sound and a stale smell of dust. The veranda is covered in dust and gravel. Her shiny black shoes are covered in dust.

In the distance are trees and grass. She would like to go to that cool green shade, away from the boys and the gravel hitting the doll's house, with its dirty peeling paint, but she stands still, glued to her spot on the veranda. The green grass seems very far away but her school bag is hanging just over there in the right place.

The lines of descent that would make this space predictable, habitual and comforting are not available to the girl at this moment, standing glued to the veranda, on her first day at preschool - except for her relation to her school bag hanging where it should be, on its hook. The boys are not unfamiliar to her, as she has two brothers of her own. But what she had imagined as possible, playing with a longed for doll's house, is not possible, and she does not yet know what movement might be possible. Still, she has her school bag and her lunch hanging in the right place, so in that sense she exists in this space. She is dressed as a schoolgirl, too, but already her shiny shoes are dusty. She stands immobile, not knowing how to be or to become a schoolgirl (Davies et al. 2001). Where is she supposed to be? What is she supposed to do? The place is loaded with 'danger'. Which movements will be taken as 'normal' and 'acceptable', or will mark her as 'unacceptable'? There are no obvious answers. The boys, on the other hand, seem to have found an 
answer for themselves, together creating a game they can play together that involves competition, laughter, throwing gravel, and the satisfying sound of gravel ricocheting in the separate rooms of the dolls' house. At the same time they successfully mark the dolls' house as abject - not for them to play dolls like girls would do and in so doing mark the girl as abject and other in that moment. Throwing gravel signifies I-am-a-boycompeting-with-the-other-boys, and I am appropriately becoming a boy who takes risks, who abjects the feminine, and fits, in this way, with other boys, appropriately, within the preschool. The boys thus collectively, and apparently spontaneously and naturally, territorialise the space with their own unmarked dominance, as 'the autonomous, rational subject that can smoothly move his body in accordance with what is considered acceptable and appropriate within the social sphere' (Fritsch 2015, 48).

\section{The spinning giant}

Our second memory story takes us to a child that two of us have worked with as support workers when he was little. Kobe was a boy who opened us up to moments of being that are indelibly inscribed in our hearts. He was categorised as having autism spectrum disorder and having a muscle disease and being intellectually disabled, and was often alone in the playground - unlike the boys in our first story. On this particular day one of the other boys, Xander, engaged him in a game that they could play together, momentarily de-territorialising the categorisation of Kobe as one who cannot engage with others.

It's playtime. Kobe is spinning on the playground. He turns around, around and around with his arms wide open, his hair flying in the wind. When he stops, he loses his balance. He laughs with a big smile and his eyes sparkle. He starts again.

Suddenly Xander bumps into him. They both stop, lose their balance and look at each other. For a moment nothing happens, they just stare. Kobe starts spinning again.

Xander comes closer and gives him a hard shove. The children who are playing nearby come closer and make a circle. They look with curiosity to discover what will happen between Xander and Kobe. Xander is totally focused on Kobe, and he pushes him again. But Kobe doesn't react, his body doesn't move. Both feet stay solidly on the ground, his arms next to his body, his face staying still.

Xander takes a step closer and gives Kobe another hard shove and runs off. Kobe wobbles, finds his balance, and follows Xander with his eyes.

Xander is almost at the other end of the playground. This looks like a signal for Kobe to gather all of his energy and start running after Xander. A second later the group of children flocks after him. Kobe runs like a clumsy, tiny giant. He makes very big slow movements and every time his feet touch the ground it makes a lot of noise. His hands reach in front of his body, as if they could reach Xander any minute. Kobe screams: 'aggrrrrr'. He can't keep up with Xander.

All of a sudden Xander turns and runs after Kobe. Kobe stops and freezes, his glasses crooked on his nose. He laughs. When Xander comes close to him, he slows down and yells: 'Run Kobe, Run Kobe'! Kobe waits a moment and then he turns and runs away from Xander. He laughs and screams loudly. The school bell rings and everybody goes to line up. Kobe is still running after nobody ... He is all alone once more. 
When Kobe was spinning, he created his own place, his own small world; a place where he could simply spin, a space where he could enjoy his own presence, his own body. The world of Kobe and the outside world of other people appeared to be entirely separate from each other when he was spinning. There was no visible encounter with others. His spinning, the repetition and the aloneness, was the characteristic that defined him as autistic.

Although play is usually defined as not following prescriptions and not needing to be 'productive' (Caillois 2001), Kobe's spinning was not seen as the free-flowing open-ended movement that normative children should engage in when they play. It was, instead, a marker of his individual, embodied, pathologised condition. Teachers and support staff kept an eye on him and observed his successes and failures closely. He was usually seen not as 'Kobe', but as the one categorised as 'autistic' and 'intellectually disabled' with 'impaired motor skills'. His categorisation was central to the way people looked at him.

The spinning activity could have continued for minutes, or hours. But through the encounter with Xander, Kobe was pulled in this moment of being into visible intraaction with others. We do not know if Xander initially bumped Kobe accidentally or with intent. It does not matter. What happened was that Kobe and Xander (and all the other children around) affected each other. 'Affects', in this Deleuzian sense, are surprising. They come from 'the forces that pass between the parties, which provoke a change of state and create something new in them' (Davies 2014, 61).

This intra-action between Xander and Kobe can lead us to further question our takenfor-granted ways of thinking; what do we see as play? Is this play or not? Is this tag? Or is this bullying? Xander's 'interference' was not confined to an individual body: it flowed inbetween, affecting what might happen in the playground. It was not only involving Kobe and Xander but also the children around them, flocking after them, becoming one with Kobe and Xander.

Xander made contact with Kobe, searching for the possibility of opening up something new. He did not know if and how Kobe would respond, but he was open to including Kobe in his play. He did not close down the possibilities. He experimented, and through that experimentation, he intra-acts, with Kobe, that is, he affects Kobe and is affected by him, opening up the possibility that Kobe can play together with him and with the other children. He did this in a very physical way, pushing Kobe. This could also be dangerous, as any line of ascent might always be. If the teacher had seen it, it may have been disallowed, since it could easily have been read as 'teasing' Kobe, or Xander being too rough.

Xander was the only boy who played with Kobe, not on a regular basis but sometimes. There was little or no contact with the other boys in his class - boys who assumed themselves and each other to be normal; he was not recognisably 'one of the boys', though in that moment of flocking, initiated by Xander, he was. Kobe was more usually on the margins of collective boys' playing; he was seen as a boy who could not play, or his play was not good enough, or not masculine enough. He mostly intra-acted in the classroom, and on the playground, with the girls of his class, who took care of him, finding in him an other who could let them play out being good nurturing (normalised) girls.

Xander was very popular with the boys: he was physically strong and had a lot of courage; he took risks, broke the rules, and was always searching for adventure. The 
teachers had Xander on their radar. In the classroom, he was not the best of students, and because of his tough way of intra-acting, he received many negative comments from teachers. Yet here, in this moment of being, he opened up an encounter with Kobe that gave them both pleasure. Both appeared to feel good and happy as they opened up to this encounter with each other and with the other boys. Kobe's body expressed pleasure in the way he ran to catch Xander, and he 'got' the sudden switch to running away, his whole body taken up with the pleasure of running, face lit up with smiling, the sound of pleasure and excitement spilling from his body - a pleasure he did not let go of, even when the group had disbanded; Xander and Kobe had fun, their play was dynamic, together they created an 'emergent intracorporeal multiplicity' (Fritsch 2015, 51).

\section{The red pyramid}

Our next story takes us to children playing together on a red pyramid in the playground. Here there is a reverse movement to the one we witnessed in the second story. Here the memory begins with the girl playing with the other girls as if she was normal and is positioned by her teacher as having behaved inappropriately:

It was playtime. My classmates and I straightaway headed towards the red pyramid. Some of my friends jumped on it, rushing towards the top or looking from above at the progress that those below were making. I put on my brakes. I was being cautious for once. I grabbed my legs, picked them up, and swung them over the lowest bar. Like a monkey I grabbed the bar above with my hands and pulled myself up without any effort. In turn, my classmates below made sure my legs were following along while I was making my way to the top of the pyramid. Sometimes my friends above or beside me would move out of the way so I could grab the bar closest to me. I enjoyed the smoothness of climbing. I felt powerful. I felt light. Fast thinking, and fast acting. I also loved the feeling of adventure. I was free to choose where to go. Not a single step, not a single wheelchair barrier was hindering me, or compromising my options. Above all, I was surrounded by my friends, having quality time.

\section{And then suddenly: INGE! WHAT ARE YOU DOING?! GET OFF THERE! NO! STAY THERE! DON'T} MOVE!

Her message was clear: I was not supposed to be on the pyramid in the middle of the school's playground. It was dangerous.

My heart beating, the rest of my body blocked. The feeling of guilt, of being busted. The teacher screaming. Out of nowhere. In my head, she was screaming hysterically. The fun was over. I had not reached the top yet and I was not going to anymore.

The teacher's scream highlighted the fact that the girl was doing something extraordinary, but that was not what the girl felt at first. She had become a wrong-doer, not knowing what exactly she was doing wrong. She was behaving like her friends and they were playing in the playground. Surely there would not be things on the playground that were not to be played on? She and her friends had not climbed the pyramid to be naughty. She would not even dare to think of breaking the rules. It was simply playtime, the teacher took them to the playground to have fun, and they all wanted to play together. She and her friends all worked towards the same goal: reaching the top. And yet, the teacher seemed scared and angry at her, only at her. She was singled out, and the only obvious difference between her and her friends was that wheelchair waiting for her down at the bottom of the pyramid. She was aware of that, even as a five-year old. 
The girl thus knew she was not allowed to be with and like her friends. She sensed that the teacher did not trust her, and that the teacher assumed she was not able to act like her friends. And yet for her, climbing was effortless. Her arms were strong, and so was her insight into the structure of the pyramid. She knew which bars to grab. The only challenge was to avoid hurting her legs, and her friends were taking care of that.

This is an ambiguous moment of citational repetition; the teacher seeks to protect the child, and she violently wrests the child into the category of one who cannot be granted normality. It is interesting that the girl's friends did not share the teacher's alarm. They did not see any problem in their friend joining them - including her in climbing the pyramid was normal. Even helping her was self-explanatory. Some of them had positioned themselves strategically around and below her, ready to carry her legs for her and to take over her legs from each other. Those above made sure they opened up spaces for their friends below. Climbing the red pyramid together was fun. They did not separate her out as one who is not part of their friendship community, but opened themselves up to an encounter with the pyramid and each other - in a mutual encounter that opened them up to a line of ascent in which they could experiment with the not-yet-known of climbing the red pyramid. They had climbed together as a community of equals, intra-actively working towards the same goal. Together they had found a 'line of ascent', all taking part in the risky business of the climb. They formed an 'emergent intracorporeal multiplicity' (Fritsch 2015, 51), functioning together as one organism with diverse functions, an organism that could find its way on this exciting line of ascent. Whereas boys in our first story enjoyed the pleasure of taking risks as integral to being boys-playing-together, here the girl is found to be seriously in error for having taken what the teacher regards as a risk. Risk-taking, and the associated lines of flight, become in this moment both gendered and linked to membership of the unmarked category of being-abled.

\section{So how do gender, disability and imagination work together in each of these encounters?}

Each of these stories involves a threshold (De Schauwer and Davies 2015). There is a pause before the threshold. In that pause there is an unanswerable question. Can the girl on the veranda step off the veranda and, in a line of flight into the not-yet-known, run toward the trees and the cool grass? Can Kobe engage with the other boys and play chasing with them? Can the girl on the red pyramid climb to the top after the teacher screams? Each one is locked in their moment, each one momentarily overwhelmed with the impossibility of playing, or intra-acting like a normal child. It is in their intra-actions with others - other children or caregivers - that the possibility of stepping across the threshold can be opened up, allowing the lifeblood to flow.

The girl on the veranda finds herself locked into her moment of isolation. The girl does not bring her isolation with her to school in her own body; nor is it part of any category she has been assigned to; it is a state that emerges, taking over her body, in intra-action with the boys and their emergent masculinity, the gravel, the doll's house and the preschool veranda; there are multiple entangled players. Their embodied beings are integral to an assemblage much larger than their individual bodies. An already existing idea of gender is being materialised; it is a public space and the boys know, through throwing the gavel and laughing together, that in this space dolls are for girls and they must establish 
themselves as other to girls and dolls, and also other to the girl on the veranda. In displaying their noisy, competitive gravel-throwing, they emerge, in intra-action with each other's bodies, and with the beings they abject, as competent, risk-taking, masculine boys. In standing glued to the veranda, the girl emerges as passive to their active, subordinate in the face of their ascendance, and as integral to whatever it is that the boys, collectively, are abjecting. This is the emergent space opened up for her, and for the boys, in that public preschool space, a space in which there is, in that moment, no line of ascent and no creative risk-taking that she can engage in.

Kobe also finds himself alone, but he is not immobile. Unlike the girl in the first story, Kobe comes to the school with a categorisation that marks his aloneness as pathological. Yet his spinning suggests that his isolation is not a problem for him, that he even enjoys it. Xander, a popular boy, draws Kobe into the intracorporeal expression of collective masculinity along with other boys who form an active band that Kobe might join. Xander re-positions Kobe as one of the boys, and Kobe becomes for a wild and wonderful moment part of the assemblage of boys chasing each other, his category membership as autistic, intellectually disabled, and motor impaired momentarily left behind on the playground where he had been whirling. In this emergent encounter, Xander does not greet Kobe in terms of his category, but in terms of a shared masculinity that can be collectively expressed through their bumping, running, shouting bodies, and Kobe shouts with joy as he runs with-in the running group of boys, and then alone without them after the bell rings.

In our third story, the girl had faced a momentary threshold when she arrived in her wheelchair at the base of the pyramid. Rapidly, with her friends, that threshold was crossed when, without plan or discussion, the collective body of girls climbed, knowing exactly how to make the venture of climbing possible for all of them. The girl's strong arms and shoulders, and her capacity to read the structure of the pyramid were as integral to the collective climb as the work of lifting her legs so they did not get tangled or hurt. None of them were limited by any preconception that girls could not climb, or that differences were necessarily an impediment to their collective activity. As one emergent multiple body, they made their way to the top of the red pyramid. When the girl's category membership was wrenched to the fore in her teacher's scream, and her line of ascent with her friends and the pyramid ended, the girl's emergent intracorporeal multiplicity was halted and replaced with an individualised category membership - as one who must be protected from taking risks - as both feminine and disabled.

\section{(In)conclusion}

In the current neoliberal discourse, schools are required to produce individualised, autonomous, normative, responsibilised subjects who have become "'entrepreneurial actors" across all dimensions of their lives' (Brown 2003, 38). Schools are assessed, as are individual teachers, on the extent to which they can produce those ideal subjects who will above all contribute to the economy. When a new policy is enacted that requires inclusion of those children who may not be able to shape themselves into subjects who can fulfil that neoliberal ideal, schools are presented with a contradiction. A new set of criteria is developed to judge them by - the number of disabled children not previously included, who are now included, will be part of each school's assessment. The same quantitative devices are 
mobilised to realise goals that manifestly contradict each other. Teachers are currently struggling to make their way through these contradictory imperatives.

Rather than attempt to resolve those contradictions we have approached this dilemma from a different perspective, establishing an ethical framework that asks, of each moment, who and what is being made to matter? Resisting the lines of descent of categorisation and measurement (which is, in a very real sense the lifeblood of neoliberal systems of thought and practice), we invite practitioners to consider that what any of us can be in any one moment is not bound by our category membership, however powerful that might be in the imaginations of those involved.

Who we each can become, in our emergent specificity, is not carried in static bodies bounded by categories, but in intra-active, intracorporeal encounters among the children and between children and those who work with them. We become what is possible in diffractive mobile embodied encounters with others, human and otherwise. The subject, we have argued, is neither singular nor stable; it is moving within and between categories (human/non-human, male/female, (cap)able/disabled). The diffractive thinking that the methodology of collective biography made possible enabled us to analyse the practices through which subjects are differentiated - sorted into categories - and to open up in its place an idea of justice based on differenciation, on movement, where each subject, in intra-action with others can become integral to multiple ongoing assemblages. Within that emergent, intra-active, intracorporeal multiplicity, imagination becomes a tool to destabilise dominant ways of thinking and acting, enabling us to think differently, opening up what it is yet possible to become.

We have found gender to be at work in the emergent multiplicities we have explored, and to be entangled in both positive and negative ways with the categorisations that mark some children as disabled, and as such, not thinkable in terms of ascendant normative modes of being.

This brings us full circle to the concept of justice that we began with. We have opened up a space of responsibility and accountability, not the responsibilisation and audit mechanisms of neoliberal systems in which one must satisfy pre-conceived criteria with numerical scores, but a responsibility to think outside such systems, to listen to the emergent other, to understand one's own intracorporeal entanglement with that other, and to be able to make an account of what it was that was being made to matter with-in the diffractive encounters in which one's self was emergent. Our accountability is a matter of ethics - of what we have been party to making matter:

Ethics is (...) not about right responses to a radically exteriorized other, but about responsibility and accountability for the lively relationalities of becoming, of which we are a part. Ethics is about mattering, about taking account of the entangled materializations of which we are part, including new configurations, new subjectivities, new possibilities. Even the smallest cuts matter. Responsibility is then a matter of the ability to respond. Listening for the response of the other and an obligation to be responsive to the other, who is not entirely separate from what we call the self. (Barad in Dolfijn and Van der Tuin 2012,69)

\section{Notes}

1. We use the past tense here, because of the 'what about the boys' movement, which emerged globally when the unmarked ascendancy of boys was challenged by girls' increasing success 
in schools. That movement was aimed at recovering boys' (assumed to be rightful) ascendant positioning.

2. $5.2 \%$ of the student population in Flanders does not have access to regular/mainstream schooling, being placed instead in 'special' schools. Of those children, $67 \%$ have a learning disability or mild intellectual impairment or behaviour and emotional problems. A disproportionate number of them have a diverse social, cultural and linguistic background (NESSE 2012). The UN convention article 24 (2006) asserts the right to be included in the regular schooling system; and in a hearing in September 2014 the UN Committee expressed serious concern about the current situation of inclusive education in Flanders.

3. Two of the four authors of this paper have worked for many years as support workers, paid for by funds allocated by government to parents, so that parents can employ workers who work with the child both at home and at school. A lot of the work has involved making the environment accessible through adapting exercises and learning material and support children in their social contacts, and also working with the teachers on educational planning.

4. See Hoskins (2015) for a good analysis of the concept of reflexivity.

5. International Congress of Qualitative Inquiry

\section{Disclosure statement}

No potential conflict of interest was reported by the authors.

\section{References}

Baker, Carolyn, and Bronwyn Davies. 1989. "A Lesson on Sex Roles." Gender and Education 1: 59-76. Barad, K. 2007. Meeting the Universe Halfway: Quantum Physics and the Entanglement of Matter and Meaning. Durham: Duke University Press.

Barad, K. 2008. "Posthumanist Performativity: Toward an Understanding of How Matter Comes to Matter." In Material Feminisms, edited by S. Alaimo and S. Heckman, 149-156. Bloomington: Indiana University Press.

Bergson, H. 1998. Creative Evolution. Mineola: Dover.

Bird Claiborne, L., S. Conforth, B. Davies, A. Milligan, and J. White. 2009. "Inclusion and Mastery: Variations on the Theme of Subjection." Gender and Education 5: 1-14.

Brown, W. 2003. "Neo-Liberalism and the End of Liberal Democracy." Theory and Event 7 (1): 1-43.

Caillois, R. 2001. Man, Play, and Games. Urbana, IL: University of Illinois Press.

Davies, B. 1993. Shards of Glass. Children Reading and Writing Beyond Gendered Identities. Sydney: Allen and Unwin.

Davies, B. 2008. "Re-Thinking 'Behaviour' in Terms of Positioning and the Ethics of Responsibility." In Critical Readings in Teacher Education. Provoking Absences, edited by A. M. Phelan and J. Sumsion, 173-186. Netherlands: Sense.

Davies, B. 2009. "Difference and Differentiation." In Pedagogical encounters, edited by B. Davies and S. Gannon, 17-31. New York: Peter Lang.

Davies, B. 2014. Listening to Children: Being and Becoming. London: Routledge.

Davies, B. Forthcoming. Emergent Listening. ICQI Proceedings. California: Left Coast Press.

Davies, B., and S. Gannon. 2006. Doing Collective Biography. Maidenhead: Open University Press.

Davies, B., A. B. Flemmen, S. Gannon, C. Laws, and B. Watson. 2006a. "An Archaeology of Power and Knowledge." In Doing Collective Biography, edited by B. Davies and S. Gannon, 145-166. Maidenhead: Open University Press.

Davies, B., J. Browne, S. Gannon, E. Honan, and M. Somerville. 2006b. "Embodied Women at Work in Neo-Liberal Times and Places." In Doing Collective Biography, edited by B. Davies and S. Gannon, 61-78. Maidenhead: Open University Press.

Davies, B., and S. Gannon. 2009. Pedagogical Encounters. New York: Peter Lang. 
Davies, B., and S. Gannon. 2013. "Collective Biography and the Entangled Enlivening of Being." International Review of Qualitative Research 5 (4): 357-376.

Davies, B., S. Dormer, S. Gannon, C. Laws, H. Lenz-Taguchi, H. McCann and S. Rocco. 2001. "Becoming Schoolgirls: The Ambivalent Project of Subjectification." Gender and Education 13 (2): 167-182.

Davies, B., and R. Harré. 1990. "Positioning: The Discursive Production of Selves." Journal for the Theory of Social Behaviour 20 (1): 43-63.

Deleuze, G. 1994. Difference and Repetition. London: Continuum.

Deleuze, G., and F. Guattari. 2004. A Thousand Plateaus: Capitalism and Schizophrenia. Translated by B. Massumi. London: Continuum.

De Schauwer, E., and B. Davies. 2015. "Crossing Thresholds with a Child with a Disability." Departures in Critical Qualitative Research 4 (4): 83-98.

Dolfijn, R., and I. Van der Tuin. 2012. New Materialism: Interviews and Cartographies. Michigan: Open Humanity Press.

Foucault, M. 1997. "Technologies of the Self". In Michel Foucault: Ethics, Subjectivity and Truth, edited by P. Rabinow, Essential Works of Foucault 1954-1984 Vol 1. (R. Hurley trans.), 223-252. New York: New Press.

Fritsch, K. 2015. "Desiring Disability Differently: Neoliberalism, Heterotopic Imagination and IntraCorporeal Configurations." Foucault Studies 19: 43-66.

Hall, E. 2013. "Making and Gifting Belonging: Creative Arts and People with Learning Difficulties." Environment and Planning A 45 (2): 244-262.

Hehir, T. 2005. New Directions in Special Education: Eliminating Ableism in Policy and Practice. Cambridge, MA: Harvard Education.

Hoskins, K. 2015. "Researching Female Professors: The Difficulties of Representation, Positionality and Power in Feminist Research." Gender and Education 27 (4): 393-411.

Kafer, A. 2013. Feminist, Queer, Crip. Bloomington: Indiana University Press.

Kimmel, M. 1990. "After Fifteen Years: The Impact of the Sociology of Masculinity on the Masculinity of Sociology." In Men, Masculinities and Social Theory, edited by J. Hearn and D. Morgan, 93-109. London: Unwin Hyman.

Lather, P., and E. A. St. Pierre. 2013. "Post-Qualitative Research." International Journal of Qualitative Studies in Education 26 (6): 629-633.

Laws, C. \& B. Davies. 2000. "Poststructuralist Theory in Practice: Working with 'Behaviourally Disturbed' Children." International Journal of Qualitative Studies in Education 13 (3): 205-221.

Malins, P. 2007. "City Folds: Injecting Drug Use and Urban Space." In Deleuzian Encounters. Studies in Contemporary Social Issues, edited by A. Hickey-Moody and P. Malins, 151-168. Houndmills: Palgrave Macmillan.

Martin, E. 1997. "Designing Flexibility: Science and Work in an Age of Flexible Accumulation." Science and Culture 6 (28): 327-362.

Masschelein, J., and M. Simons. 2005. "The Strategy of the Inclusive Education Apparatus: Inclusive Education for Exclusive Pupils." Studies in Philosophy and Education 24 (2): 117-138.

NESSE. 2012. Education and Disability/Special Needs Policies and Practices in Education, Training and Employment for Students with Disabilities and Special Educational Needs in the European Union. http://europa.eu/rapid/press-release_IP-12-761_en.htm.

Rose, N. 1989. Governing the Soul: The Shaping of the Private Self. 2nd ed. London: Free Association. Shildrick, M. 2002. Embodying the Monster: Encounters with the Vulnerable Self. London: Sage Publications.

Simons, M., and J. Masschelein. 2008. "The Governmentalization of Learning and the Assemblage of a Learning Apparatus." Educational Theory 58 (4): 391-415. 